\title{
Assembly of Nanostructured Films with Hydrophobic Subcompart- ments via Continuous Assembly of Polymers
}

\author{
Edgar H. H. Wong, Martin P. van Koeverden, Eunhyung Nam, Stefanie N. Guntari, Steven Harris \\ Wibowo, Anton Blencowe,† Frank Caruso,* and Greg G. Qiao*
}

Department of Chemical and Biomolecular Engineering, The University of Melbourne, Parkville, Victoria 3010, Australia.

KEYWORDS: controlled radical polymerization, micelles, diblock copolymers, surface initiated polymerization, thin films, grafting through

\begin{abstract}
The generation of nanoscale polymer films using complex, hierarchically structured (bio)macromolecular architectures has important implications in the field of materials science. This study details the surface-confined covalent cross-linking of micellar macrocross-linkers derived from the amphiphilic diblock copolymer, polystyrene- $b$-poly $(N-(2-$ hydroxypropyl)methacrylamide), via atom transfer radical polymerization (ATRP)-mediated continuous assembly of polymers ( $\mathrm{CAP}_{\text {АтRP }}$ ), to generate compartmentalized thin films with unique surface morphologies. Using initiator-functionalized silicon wafers, the micellar films were found to be thicker in comparison to thin films prepared from linear macrocrosslinkers derived from poly( $N$-(2-hydroxypropyl)methacrylamide) (15.2 vs $10.2 \mathrm{~nm}$ ). Unlike the smooth and flat surface morphologies observed for films prepared from the linear macrocross-linker, the micellar films possessed distinctive pitted morphologies that became more pronounced after annealing. Furthermore, the hydrophobic polystyrene cores of the micelles enabled the encapsulation of hydrophobic molecules that subsequently remain compartmentalized during the CAP process, as demonstrated with the encapsulation of the dye, Nile Red. The assembly of Nile Red loaded micelles onto initiator-functionalized silica particles was confirmed via fluorescence microscopy. This study demonstrates the efficiency and versatility of the CAP approach to generate nanostructured thin films with controllable morphology, surface roughness, thickness and composition, simply by varying the macromolecular architecture.
\end{abstract}

\section{INTRODUCTION}

In recent years, thin polymer films assembled from complex (bio)macromolecular architectures, including micelles, ${ }^{1-} 7$ star polymers, ${ }^{8-}{ }^{15}$ liposomes or polymersomes, ${ }^{16-18}$ or dendrimers, ${ }^{19,20}$ have received significant interest as a result of their ability to impart specific functionalities that are desirable for a diverse range of applications, including drug delivery, biomimicry, catalysis, and electronics. For example, films composed of micellar/dendritic architectures exhibit superior drug encapsulation and release capabilities in comparison to films made from their linear polymeric counterparts. 3 In addition, micelles with hydrophobic cores have enabled the effective incorporation of water-insoluble molecules into multilayer polyelectrolyte thin films, which is difficult to achieve using linear polymers.1 Alternatively, the use of polymersomes in film assembly, combined with a controlled annealing process, has enabled the precise tuning of nanoscale surface roughness, which could prove to be beneficial for microelectronics. ${ }^{16}$ The layer-by-layer (LbL) ${ }^{21,22}$ approach, which relies on the sequential deposition of polymers bearing complementary functionality (e.g., polycation and polyanion), has been widely used for the fabrication of architecturally diverse films, as this technique allows the physicochemical properties to be tuned with nanoscale resolution. Although the LbL method is robust and versatile, the inherent multi-step procedure can be laborious and time consuming. While grafting-from ${ }^{23,24}$ and grafting-to 25,26 methodologies are highly effective in generating polymeric brush films, there are limited examples that describe the successful grafting of complex macromolecular architectures onto surfaces 6 as a result of associated synthetic challenges. For example, the graftingfrom approach does not easily permit the construction of architecturally complex films from small molecule monomers or cross-linkers, while the grafting-to approach typically generates a monolayer.

Recently, we developed a strategy to fabricate nanoscale films via the continuous assembly of polymers (CAP), a technique that involves the controlled chain-growth polymerization of macrocross-linkers (i.e., preformed (bio)macromolecules modified with pendent polymerizable moieties) from initiator-functionalized substrates to afford cross-linked, surface-confined, ultrathin films with tailored properties. ${ }^{27-31}$ The CAP technique allows the formation of nanoscale films with tunable composition and thickness, controlled by reaction time, macrocross-linker composition, and/or type of controlled polymerization technique employed. Using the CAP process, cross-linked films can be generated continuously through propagation/cross-linking reactions via the polymerizable groups 
of the macrocross-linker. Only minimal amounts of polymerizable groups are necessary for a successful CAP process $(>7 \%) .^{30}$ In addition, the versatility of the CAP technique allows the efficient preparation of cross-linked films with complex macromolecular architectures in a single step.

In this study, we demonstrate that the CAP approach can be employed for the efficient and facile fabrication of thin films with pitted surface morphologies and segregated hydrophobic domains, through the use of micelle-based macrocross-linkers. Specifically, a macrocross-linker based upon the amphiphilic diblock copolymer, polystyrene- $b$ poly( $N$-(2-hydroxypropyl)methacrylamide), which forms micelles in water, was employed in the atom transfer radical polymerization (ATRP) ${ }^{32,33}$-mediated CAP process

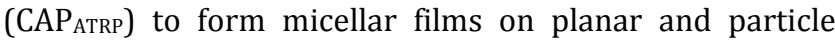
substrates (Scheme 1). The micellar macrocross-linkers are cross-linked in situ on the substrate during CAPATRP, thereby locking the core-shell architecture of the micelles into the films. This was confirmed through encapsulation of hydrophobic molecules within the polystyrene micelle cores that were then incorporated into the films. It is anticipated that the described strategy will open up new avenues in the fabrication of functional thin films for advanced (bio)applications.

Scheme 1. Formation of Thin Films with Hydrophobic

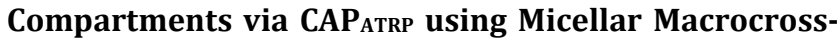
linkers

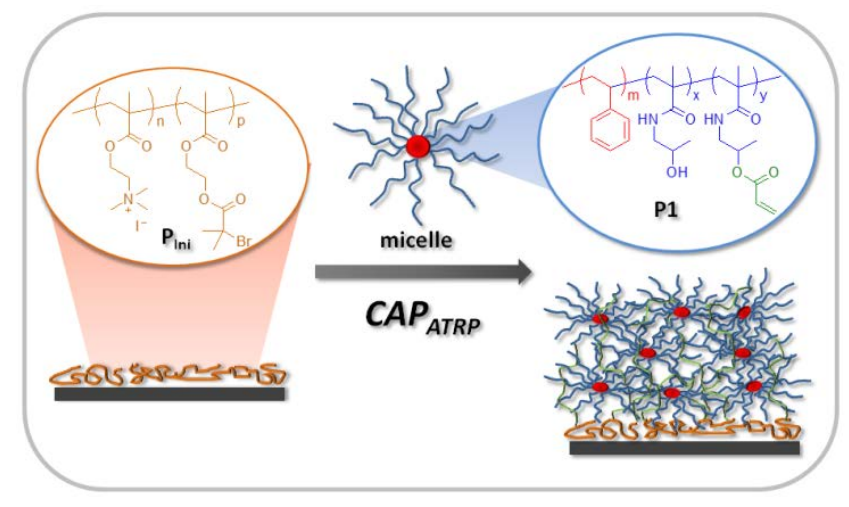

\section{EXPERIMENTAL SECTION}

Materials.

4-Cyano-4-

(phenylcarbonothioylthio)pentanoic acid (CPAD, > 97\%), $\mathrm{N}, \mathrm{N}$-dimethylacetamide (DMAc, 99\%), anhydrous $\mathrm{N}, \mathrm{N}$ dimethylformamide (DMF, 99.8\%), hexylamine (99\%), maleimide (99\%), hyperbranched polyethyleneimine (PEI, $M_{\mathrm{w}} \sim 25000$ g.mol-1), poly(sodium 4-styrenesulfonate) (PSS, $M_{\mathrm{w}} \sim 70000$ g.mol-1), copper (I) chloride (CuCl, 97\%), 2,2'-bipyridine ( $\geq 99 \%$ ), $\alpha$-bromoisobutyryl bromide (98\%), iodomethane ( $\geq 99 \%)$, copper(II) bromide $\left(\mathrm{CuBr}_{2}\right.$, $99 \%)$, sodium ascorbate $(\geq 98 \%)$ ), phenylhydrazine (97\%), tris(2-aminoethyl)amine $(96 \%)$, formic acid $(\geq$ $95 \%$ ), formaldehyde solution (38 wt\% in water), pyrene (98\%) and Nile Red $(\geq 98 \%)$ were obtained from Aldrich and used as received. $\mathrm{N}$-(2Hydroxypropyl)methacrylamide (HPMA, Polysciences, >
99\%), acryloyl chloride (Merck, $\geq 96 \%$ ), triethylamine (Scharlau, 99\%) and 2,2'-azobis(2-methylpropionitrile) (AIBN, Acros, 98\%) were used as received. Styrene (Aldrich, $\geq 99 \%$ ) and 2-(dimethylamino)ethyl methacrylate (DMAEMA, Aldrich, 98\%) were destabilized by elution through columns of basic alumina (Scharlau). 2Hydroxyethyl methacrylate (HEMA, Aldrich, 98\%) was purified according to a literature procedure. ${ }^{34}$ Tris(2(dimethylamino)ethyl) amine ( $\mathrm{Me}_{6} \mathrm{TREN}$ ) was synthesized according to a literature procedure. ${ }^{35}$ Sodium hydrogen carbonate $\left(\mathrm{NaHCO}_{3}\right)$, methanol $(\mathrm{MeOH})$, iso-propyl alcohol (iPrOH), dichloromethane (DCM), diethyl ether (DEE) and tetrahydrofuran (THF) were obtained from Chem-Supply and used as received. Magnesium sulfate $\left(\mathrm{MgSO}_{4}\right.$, anhydrous) was obtained from Merck and used without further purification. Anhydrous, deoxygenated DCM was obtained by distillation under argon from $\mathrm{CaH}_{2}$. Deuterated chloroform $\left(\mathrm{CDCl}_{3}\right)$, dimethylsulfoxide (DMSO- $\left.d_{6}\right)$, and deuterium oxide $\left(\mathrm{D}_{2} \mathrm{O}\right)$ were obtained from Cambridge Isotope Laboratories and used as received. High-purity water with a resistivity of > $18 \mathrm{M} \Omega . \mathrm{cm}$ was obtained from an in-line Millipore RiOs/Origin water purification system. Non-porous silica $\left(\mathrm{SiO}_{2}\right)$ particles (5 wt\% suspensions, average diameter $3.08 \pm 0.13 \mu \mathrm{m}$ ) were obtained from Microparticles GmbH (Berlin, Germany). Silicon (Si) wafers (MMRC Pty. Ltd., Melbourne, Australia) were cut to approximately $1 \times 1$ cm slides and cleaned with Piranha solution (99.8\% sulfuric acid:30\% hydrogen peroxide (7:3)) - Caution! Piranha solution is highly corrosive and extreme care should be taken during preparation and use. The slides were then sonicated in isopropanol:water (1:1) solution for $15 \mathrm{~min}$, heated to $60{ }^{\circ} \mathrm{C}$ for $20 \mathrm{~min}$ in RCA solution (water:30\% ammonium hydroxide:30\% hydrogen peroxide (5:1:1)), rinsed with Milli-Q and dried under a $\mathrm{N}_{2}$ stream. The slides were washed thoroughly with Milli-Q water between each step. All slides were prepared fresh prior to every CAP reaction.

Instrumentation. Polymer molecular weight characterization was carried out via gel permeation chromatography (GPC) using either DMF or water as the mobile phases. GPC analysis using DMF as the eluent was conducted on a Shimadzu liquid chromatography system equipped with a PostNova PN3621 MALS detector $(\lambda=532 \mathrm{~nm})$, Shimadzu RID-10 refractometer $(\lambda=633 \mathrm{~nm})$ and Shimadzu SPD-20A UV-Vis detector, using three Phenomenex Phenogel columns in series $\left(500,10^{4}\right.$ and $10^{6} \AA$ porosity, $5 \mu \mathrm{m}$ diameter bead size,) operating at $75{ }^{\circ} \mathrm{C}$. DMF with 0.05 mol. $\mathrm{L}^{-1} \mathrm{LiBr}$ (> 99\%, Aldrich) was employed as the mobile phase at a flow rate of 1 mL.min ${ }^{-1}$. NovaMALS software (PostNova Analytics) was used to determine the molecular weight characteristics using calculated $\mathrm{d} n / \mathrm{d} c$ values. GPC analysis using water as the eluent was conducted on a Shimadzu liquid chromatography system equipped with a Shimadzu RID-10 refractometer $(\lambda=633 \mathrm{~nm})$, using three Waters Ultrahydrogel columns in series ((i) $250 \AA$ porosity, $6 \mu \mathrm{m}$-diameter bead size; (ii) and (iii) linear , $10 \mu \mathrm{m}$ diameter bead size) operating at $60{ }^{\circ} \mathrm{C}$. Milli-Q water containing $50 \mathrm{mM} \mathrm{NaNO}$ (Chem-Supply, AR grade) and 0.02 $\mathrm{w} / \mathrm{v} \% \mathrm{NaN}_{3}$ (Chem-Supply, AR grade) was used as the mobile phase at a flow rate of $1 \mathrm{~mL}^{\mathrm{min}}{ }^{-1}$. The molecular weight characteristics of the analytes were determined 
with reference to a conventional column calibration with narrow molecular weight distribution poly(ethylene glycol) standards.

Dynamic light scattering (DLS) measurements were performed on a Wyatt DynaPro NanoStar DLS/SLS instrument with a GaAs laser (658 nm) at an angle of $90^{\circ}$ and a temperature of $25 \pm 0.1{ }^{\circ} \mathrm{C}$. Initial sample concentrations of 10 mg.mL $L^{-1}$ in water or DMF were used, then serial dilutions were performed until stable spectra were obtained. All sample solutions were filtered through $0.45 \mu \mathrm{m}$ syringe filters.

${ }^{1} \mathrm{H}$ Nuclear magnetic resonance (NMR) spectroscopy was conducted on a Varian Unity $400 \mathrm{MHz}$ spectrometer operating at $400 \mathrm{MHz}$, using the deuterated solvent $\left(\mathrm{CDCl}_{3}\right.$, DMSO- $d_{6}$ or $\mathrm{D}_{2} \mathrm{O}$ ) as reference and a sample concentration of approximately $20 \mathrm{mg} \cdot \mathrm{mL}^{-1}$.

UV-Vis spectrophotometry was performed on a Shimadzu UV-2101PC spectrometer using quartz cuvettes with a 1 $\mathrm{cm}$ path length.

Atomic force microscopy (AFM) images of dried films on silicon wafers were acquired with an Asylum Research MFP-3D atomic force microscope. Typical scans were conducted in AC mode with ultrasharp SiN gold-coated cantilevers (MikroMasch, Bulgaria). Image processing and surface roughness analysis were performed using the Nanoscope and Igor Pro software programs, respectively. CAP film thicknesses were estimated by scratch analysis (mechanical removal of the film) and by tracing a profile along the film and the scratched zone. The thickness measurements reported represent mean values over five different analysis areas per substrate.

Contact angle measurements were recorded using a Data Physics OCA 20 Tensiometer. Measurements were recorded with OCA software using a sessile drop profile.

Fluorescence microscopy of the CAP particles were performed on an inverted Olympus IX71 microscope equipped with a UF1032 fluorescence filter cube, and a 60× oil immersion objective (Olympus UPFL20/0.5NA, W.D 1.6).

Synthesis of Macrocross-linker P1. Macrocross-linker P1 was prepared in three-steps: i) synthesis of the hydrophobic polystyrene (PS) block via reversible addition fragmentation chain transfer (RAFT) ${ }^{36,37}$ polymerization; ii) chain extension with the hydrophilic monomer HPMA to form the amphiphilic diblock copolymer; and iii) partial esterification of the hydroxyl groups with acryloyl chloride.

AIBN (9.9 mg, $60.0 \mu \mathrm{mol}$ ) and CPAD (67 mg, $240 \mu \mathrm{mol})$ were dissolved in styrene $(3.0 \mathrm{~g}, 28.9 \mathrm{mmol})$ and the mixture was degassed by bubbling with $\mathrm{N}_{2}$ for $30 \mathrm{~min}$ at $0{ }^{\circ} \mathrm{C}$. The reaction was stirred at $80{ }^{\circ} \mathrm{C}$ for $20 \mathrm{~h}$ under $\mathrm{N}_{2}$ and then cooled in an ice bath. The monomer conversion was determined to be $c a$. $60 \%$ by ${ }^{1} \mathrm{H}$ NMR spectroscopic analysis. The crude mixture was diluted with DCM (6 mL), precipitated into $\mathrm{MeOH}(100 \mathrm{~mL})$, and the precipitate was isolated via centrifugation. This precipitation was repeated twice more and the precipitate was dried in vacuo to afford the PS macroinitiator as a pink powder, $1.0 \mathrm{~g}$ (33\%). GPC (DMF): $\mathrm{d} n / \mathrm{d} c=0.137 \mathrm{~mL} \cdot \mathrm{g}^{-1} ; M_{\mathrm{n}}=10200 \mathrm{~g} \cdot \mathrm{mol}^{-1}, M_{\mathrm{w}}=10$ 700 g.mol ${ }^{-1}, Ð=1.05 .{ }^{1} \mathrm{H}$ NMR (400 MHz, $\left.\mathrm{CDCl}_{3}, 25^{\circ} \mathrm{C}\right): \delta_{\mathrm{H}}$ $(\mathrm{ppm})=7.20-6.30(\mathrm{~m}, 5 \mathrm{H}, \mathrm{ArH}) ; 2.10-1.60\left(\mathrm{~m}, 1 \mathrm{H}, \mathrm{CHCH}_{2}\right)$; 1.60-1.10 (m, 2H, $\left.\mathrm{CHCH}_{2}\right)$.

The PS macroinitiator (430 mg), HPMA (430 mg, 2.98 mmol), and AIBN (3.5 mg, $21.3 \mu \mathrm{mol})$ were dissolved in DMAc ( $4.2 \mathrm{~mL}$ ) and degassed by bubbling with $\mathrm{N}_{2}$ for 30 $\min$ at $0{ }^{\circ} \mathrm{C}$. The reaction was heated to $60^{\circ} \mathrm{C}$ for $18 \mathrm{~h}$ under $\mathrm{N}_{2}$ and then cooled in an ice bath. Immediately, a solution of hexylamine ( $56 \mu \mathrm{L}, 430 \mu \mathrm{mol})$, triethylamine $(18$ $\mu \mathrm{L}, 128 \mu \mathrm{mol}$ ), and maleimide ( $42 \mathrm{mg}, 430 \mu \mathrm{mol}$ ) was added to the reaction mixture to induce aminolysis and in situ thiol-Michael addition. The mixture was left to stir for $1 \mathrm{~h}$ at $25{ }^{\circ} \mathrm{C}$ and then dialyzed against Milli-Q water $(3 \times 500$ $\mathrm{mL}, 4 \mathrm{~h})$ and $\mathrm{MeOH}(2 \times 500 \mathrm{~mL}, 4 \mathrm{~h})$. The dialyzed solution was precipitated into cold DEE ( $\left.\mathrm{ca} .4^{\circ} \mathrm{C}, 45 \mathrm{~mL}\right)$, and the precipitate was isolated via centrifugation and dried in vacuo at $45{ }^{\circ} \mathrm{C}$ to afford the diblock as a light orange solid, $650 \mathrm{mg}(70 \%) .{ }^{1} \mathrm{H}$ NMR spectroscopic analysis revealed the formation of the polystyrene- $b$-poly $(N-(2-$ hydroxypropyl)methacrylamide) (PS- $b$-PHPMA) diblock copolymer with a styrene:HPMA molar ratio of $1: 1.2$. GPC

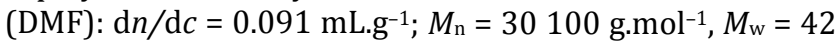
200 g.mol ${ }^{-1}, \oplus=1.40 .{ }^{1} \mathrm{H} \mathrm{NMR}\left(400 \mathrm{MHz}\right.$, DMSO- $\left.d_{6}, 25^{\circ} \mathrm{C}\right)$ : $\delta_{\mathrm{H}}(\mathrm{ppm})=7.40-6.20(\mathrm{~m}, 6 \mathrm{H}, \mathrm{ArH}$ and $\mathrm{NH}-\mathrm{C}(=0))$; 4.784.60 (br s, $\left.1 \mathrm{H},\left(\mathrm{CH}_{3}\right) \mathrm{CHOH}\right) ; 3.75-3.52\left(\mathrm{~m}, 1 \mathrm{H},\left(\mathrm{CH}_{3}\right) \mathrm{CHOH}\right)$; 3.05-2.70 (m, 2H, CH $\left.\mathrm{H}_{2} \mathrm{NH}\right) ; 2.00-1.00(\mathrm{~m}, 5 \mathrm{H}$, polystyrene and polymethacrylamide backbones); $1.00-0.60$ (br, $6 \mathrm{H}$, $\mathrm{CH}_{3}$ ).

The PS- $b$-PHPMA diblock copolymer (210 mg, 1.15 mmol of $\mathrm{OH}$ groups) was dissolved in anhydrous DMF (2 $\mathrm{mL})$ under $\mathrm{N}_{2}$, and triethylamine $(40 \mu \mathrm{L}, 28.8 \mu \mathrm{mol})$ and then acryloyl chloride $(14 \mu \mathrm{L}, 17.3 \mu \mathrm{mol})$ were added at 0 ${ }^{\circ} \mathrm{C}$. The reaction mixture was stirred at $20{ }^{\circ} \mathrm{C}$ for $15 \mathrm{~h}$ and then precipitated into cold DEE $\left(\mathrm{ca} .4^{\circ} \mathrm{C}, 20 \mathrm{~mL}\right)$. The precipitate was isolated via centrifugation, thoroughly washed with DEE and dried in vacuo to afford macrocross-linker P1 as a light orange solid, $180 \mathrm{mg}$ (86\%). GPC (DMF):

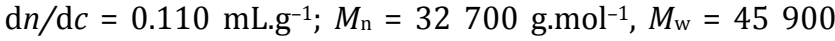
g.mol ${ }^{-1}, Ð=1.40 .{ }^{1} \mathrm{H}$ NMR (400 MHz, DMSO- $\left.d_{6}, 25{ }^{\circ} \mathrm{C}\right): \delta_{\mathrm{H}}$ $(\mathrm{ppm})=7.40-6.20(\mathrm{~m}, 6 \mathrm{H}, \mathrm{ArH}$ and $\mathrm{NHC}(=0)) ; 6.36-6.26$ $\left(\mathrm{m}, 1 \mathrm{H}, \mathrm{CH}=\mathrm{CH}_{2}\right) ; 6.18-6.02\left(\mathrm{~m}, 2 \mathrm{H}, \mathrm{CH}=\mathrm{CH}_{2}\right) ; 5.98-5.82(\mathrm{~m}$, $\left.1 \mathrm{H}, \mathrm{CH}=\mathrm{CH}_{2}\right) ; 4.94-4.80\left(\mathrm{~m}, 1 \mathrm{H},\left(\mathrm{CH}_{3}\right) \mathrm{CHO}\right) ; 4.78-4.60$ (br s, $\left.1 \mathrm{H},\left(\mathrm{CH}_{3}\right) \mathrm{CHOH}\right) ; 3.75-3.52\left(\mathrm{~m}, 1 \mathrm{H},\left(\mathrm{CH}_{3}\right) \mathrm{CHOH}\right) ; 3.05-2.70$ $\left(\mathrm{m}, 2 \mathrm{H}, \mathrm{CH}_{2} \mathrm{NH}\right) ; 2.00-1.00(\mathrm{~m}, 5 \mathrm{H}$, polystyrene and polymethacrylamide backbones); $1.00-0.60\left(\mathrm{~m}, 6 \mathrm{H}, \mathrm{CH}_{3}\right)$. The degree of esterification of hydroxyl groups was determined to be $c a$. $9 \%$ by ${ }^{1} \mathrm{H}$ NMR spectroscopy. The critical micelle concentration in water was determined to be 0.004 mg. $\mathrm{mL}^{-1}$ by fluorescence spectroscopy using pyrene as a fluorescent probe. ${ }^{38}$

Synthesis of Macrocross-linker P2. Linear poly( $N-(2-$ hydroxypropyl)methacrylamide) (PHPMA) macrocrosslinker P2 was synthesized via conventional free radical polymerization followed by the partial esterification of the hydroxyl groups with acryloyl chloride. HPMA (2.0 g, 14 $\mathrm{mmol})$ was dissolved in DMAc (6 mL) and AIBN (46 mg, $280 \mu \mathrm{mol})$ was added. The reaction mixture was degassed by bubbling with $\mathrm{N}_{2}$ for $30 \mathrm{~min}$ and then stirred at $100{ }^{\circ} \mathrm{C}$ for $2 \mathrm{~h}$ under $\mathrm{N}_{2}$. After cooling to room temperature the mixture was precipitated into THF:DEE $(1: 1,100 \mathrm{~mL})$, and 
the precipitate was isolated via centrifugation and dried in vacuo to afford PHPMA as a white solid, $1.7 \mathrm{~g}$ (84\%). GPC (DMF): $\mathrm{d} n / \mathrm{d} c=0.082 \mathrm{~mL} \cdot \mathrm{g}^{-1} ; M_{\mathrm{n}}=29800 \mathrm{~g} \cdot \mathrm{mol}^{-1}, M_{\mathrm{w}}=47$ 000 g.mol ${ }^{-1}, Ð=1.43 .{ }^{1} \mathrm{H}$ NMR (400 MHz, D $\left.20,25{ }^{\circ} \mathrm{C}\right): \delta_{\mathrm{H}}$ $(\mathrm{ppm})=7.65-7.30($ br s, $1 \mathrm{H}, \mathrm{NHC}(=0)) ; 3.85-3.65(\mathrm{~m}, 1 \mathrm{H}$, $\left.\left(\mathrm{CH}_{3}\right) \mathrm{CHOH}\right) ; 3.15-2.75\left(\mathrm{~m}, 2 \mathrm{H}, \mathrm{CH}_{2} \mathrm{NH}\right) ; 1.95-1.40(\mathrm{~m}, 2 \mathrm{H}$, $\left.\mathrm{CH}_{2} \mathrm{C}\left(\mathrm{CH}_{3}\right)\right) ; 1.05-0.70\left(\mathrm{~m}, 6 \mathrm{H}, \mathrm{CH}_{3}\right)$.

The linear PHPMA (370 mg, $2.59 \mathrm{mmol}$ of $\mathrm{OH}$ groups) was dissolved in anhydrous DMF ( $4 \mathrm{~mL}$ ) under $\mathrm{N}_{2}$, and triethylamine $(90 \mu \mathrm{L}, 650 \mu \mathrm{mol})$ and then acryloyl chloride (32 $\mu \mathrm{L}, 388 \mu \mathrm{mol}$ ) was added at $0{ }^{\circ} \mathrm{C}$. The reaction mixture was stirred for $15 \mathrm{~h}$, filtered and then precipitated into DEE (45 mL). The precipitate was isolated via centrifugation, re-dissolved in $\mathrm{MeOH}$ :water $(1: 1,4 \mathrm{~mL})$ and dialyzed against Milli-Q water $(3 \times 500 \mathrm{~mL}, 4 \mathrm{~h})$ and $\mathrm{MeOH}(2 \times 500$ $\mathrm{mL}, 4 \mathrm{~h}$ ). The dialyzed solution was precipitated into DEE (45 $\mathrm{mL}$ ), and the precipitate was isolated via centrifugation and dried in vacuo to afford macrocross-linker $\mathbf{P 2}$ as a white solid, $240 \mathrm{mg}$ (65\%). GPC (DMF): $\mathrm{d} n / \mathrm{d} c=0.090$ mL.g ${ }^{-1} ; M_{\mathrm{n}}=31500 \mathrm{~g} \cdot \mathrm{mol}^{-1}, M_{\mathrm{w}}=49100 \mathrm{~g} \cdot \mathrm{mol}^{-1}, \oplus=1.56$. ${ }^{1} \mathrm{H}$ NMR (400 MHz, $\left.\mathrm{D}_{2} \mathrm{O}, 25{ }^{\circ} \mathrm{C}\right): \delta(\mathrm{ppm})=7.65-7.30(\mathrm{br} \mathrm{s}$, $1 \mathrm{H}, \mathrm{NHC}(=0)) ; 6.36-6.26\left(\mathrm{~m}, 1 \mathrm{H}, \mathrm{CH}=\mathrm{CH}_{2}\right) ; 6.10-5.94(\mathrm{~m}$, $\left.2 \mathrm{H}, \mathrm{CH}=\mathrm{CH}_{2}\right) ; 5.92-5.80\left(\mathrm{~m}, 1 \mathrm{H}, \mathrm{CH}=\mathrm{CH}_{2}\right) ; 4.92-4.74(\mathrm{~m}, 1 \mathrm{H}$, $\left.\left(\mathrm{CH}_{3}\right) \mathrm{CHO}\right) ; 3.85-3.65\left(\mathrm{~m}, 1 \mathrm{H},\left(\mathrm{CH}_{3}\right) \mathrm{CHOH}\right) ; 3.15-2.75(\mathrm{~m}$, $\left.2 \mathrm{H}, \mathrm{CH}_{2} \mathrm{NH}\right) ; 1.95-1.40\left(\mathrm{~m}, 2 \mathrm{H}, \mathrm{CH}_{2} \mathrm{C}\left(\mathrm{CH}_{3}\right)\right) ; 1.05-0.70(\mathrm{~m}$, $\left.6 \mathrm{H}, \mathrm{CH}_{3}\right)$. The degree of esterification of the hydroxyl groups was determined to be $c a .10 \%$ by ${ }^{1} \mathrm{H}$ NMR spectroscopy.

Synthesis of Macroinitiator $P_{\text {Ini. }}$ Quaternized macroinitiator $\mathbf{P}_{\text {ini }}$ was synthesized in three steps. DMAEMA (6.92 g, $44 \mathrm{mmol}$ ), HEMA (4.69 g, $36 \mathrm{mmol}$ ), EBiB (156 mg, 0.8 mmol), and 2,2'-bipyridine (250 $\mathrm{mg}, 1.6 \mathrm{mmol}$ ) were dissolved in $i \mathrm{PrOH}(15 \mathrm{~mL})$ in a Schlenk flask with stirrer bar and degassed by three freeze-pump-thaw cycles. The solution was then frozen, the flask was backfilled with $\mathrm{Ar}$ and $\mathrm{CuCl}$ (79.2 mg, $0.8 \mathrm{mmol}$ ) was quickly added, followed by three evacuate-Ar backfill cycles. The solution was thawed, and the flask was placed in a thermostated oil bath at $25^{\circ} \mathrm{C}$ and stirred for $17 \mathrm{~h}$. The flask was cooled in liquid $\mathrm{N}_{2}$ and the solution was diluted with THF $(25 \mathrm{~mL})$ and then passed through a silica plug to remove the catalyst. The solution was precipitated into hexane $\left(-18{ }^{\circ} \mathrm{C}, 500 \mathrm{~mL}\right)$ and the precipitate was isolated via centrifugation. This precipitation was repeated and the resulting tacky residue was dried in vacuo to afford P(DMAEMA-r-HEMA) as a crystalline white solid, $5.70 \mathrm{~g}$ (49\%). The molar ratio of DMAEMA:HEMA was determined to be $1: 1$ from ${ }^{1} \mathrm{H}$ NMR spectroscopy. ${ }^{1} \mathrm{H}$ NMR $\left(400 \mathrm{MHz}, \mathrm{CDCl}_{3}, 25^{\circ} \mathrm{C}\right): \delta_{\mathrm{H}}(\mathrm{ppm})=$ $4.05\left(\mathrm{~m}, 2 \mathrm{H}, \mathrm{O}=\mathrm{COCH}_{2}\right), 3.80\left(\mathrm{~m}, 2 \mathrm{H}, \mathrm{CH}_{2} \mathrm{OH}\right), 2.56(\mathrm{~m}, 2 \mathrm{H}$, $\left.\mathrm{CH}_{2} \mathrm{~N}\left(\mathrm{CH}_{3}\right)_{2}\right), 2.32$ (br s, 6H, $\left.\mathrm{CH}_{2} \mathrm{~N}\left(\mathrm{CH}_{3}\right)_{2}\right), 2.14-1.70(\mathrm{~m}, 2 \mathrm{H}$, $\left.\mathrm{CH}_{2} \mathrm{C}\left(\mathrm{CH}_{3}\right) \mathrm{C}=0\right)$, 1.18-0.70 (m, 3H, $\left.\mathrm{CH}_{2} \mathrm{C}\left(\mathrm{CH}_{3}\right) \mathrm{C}=0\right)$.

In a dried 2 neck flask, P(DMAEMA- $r$-HEMA) (1.50 g, $5.22 \mathrm{mmol}$ of $\mathrm{OH}$ groups) and DMAP (63.8 $\mathrm{mg}, 0.52 \mathrm{mmol}$ ) were dissolved in anhydrous DCM $(20 \mathrm{~mL})$ under Ar. Triethylamine (1.1 mL, $7.89 \mathrm{mmol}$ ) was added and the solution cooled to $0{ }^{\circ} \mathrm{C}$. $\alpha$-Bromoisobutyryl bromide (800 $\mu \mathrm{L}$, $6.47 \mathrm{mmol}$ ) was then added dropwise via syringe. The reaction mixture was stirred for $1 \mathrm{~h}$ at $0{ }^{\circ} \mathrm{C}$, slowly warmed to room temperature, and stirred for $20 \mathrm{~h}$. The reaction mixture was diluted with DCM (100 mL), and washed with Milli-Q water $(2 \times 15 \mathrm{~mL})$, saturated $\mathrm{NaHCO}_{3}(2 \times 15 \mathrm{~mL})$ and brine $(20 \mathrm{~mL})$. The organic phase was dried over $\mathrm{MgSO}_{4}$, filtered, concentrated in vacuo to $\mathrm{ca} .15 \mathrm{~mL}$ in volume and then precipitated dropwise into cold hexane $(-18$ ${ }^{\circ} \mathrm{C}, 300 \mathrm{~mL}$ ). The precipitate was collected by centrifugation and dried in vacuo to afford P(DMAEMA- $r$-BIEM) as a crystalline yellow solid, $998 \mathrm{mg}$ (44\%). The degree of esterification was determined to be $>95 \%$ by ${ }^{1} \mathrm{H}$ NMR spectroscopy. ${ }^{1} \mathrm{H}$ NMR $\left(400 \mathrm{MHz}, \mathrm{CDCl}_{3}, 25^{\circ} \mathrm{C}\right): \delta_{\mathrm{H}}(\mathrm{ppm})=4.34$ $\left(\mathrm{m}, 2 \mathrm{H}, \mathrm{CH}_{2} \mathrm{OC}(=\mathrm{O})\left(\mathrm{CH}_{3}\right)_{2} \mathrm{Br}\right), 4.16\left(\mathrm{~m}, 2 \mathrm{H}, \mathrm{O}=\mathrm{COCH}_{2}\right), 4.02$ $\left(\mathrm{m}, 2 \mathrm{H}, \mathrm{O}=\mathrm{COCH}_{2}\right), 2.53\left(\mathrm{~m}, 2 \mathrm{H}, \mathrm{CH}_{2} \mathrm{~N}\left(\mathrm{CH}_{3}\right)_{2}\right), 2.25$ (br s, $\left.6 \mathrm{H}, \mathrm{CH}_{2} \mathrm{~N}\left(\mathrm{CH}_{3}\right)_{2}\right), 1.93$ (br s, 6H, OC(=O) $\left.\left(\mathrm{CH}_{3}\right)_{2} \mathrm{Br}\right), 2.14-$ $1.70\left(\mathrm{~m}, 2 \mathrm{H}, \quad \mathrm{CH}_{2} \mathrm{C}\left(\mathrm{CH}_{3}\right) \mathrm{C}=0\right), \quad 1.18-0.70 \quad(\mathrm{~m}, 3 \mathrm{H}$, $\left.\mathrm{CH}_{2} \mathrm{C}\left(\mathrm{CH}_{3}\right) \mathrm{C}=0\right)$.

P(DMAEMA-r-BIEM) (998 mg, $2.29 \mathrm{mmol}$ amino groups) was dissolved in THF: $\mathrm{H}_{2} \mathrm{O}(1: 1,30 \mathrm{~mL})$ and the $\mathrm{pH}$ was adjusted to $c a$. pH 9 with $1 \mathrm{M} \mathrm{NaOH}$ solution. Iodomethane (428 $\mu \mathrm{L}, 6.86 \mathrm{mmol}$ ) was added dropwise and the solution was stirred vigorously at room temperature for $24 \mathrm{~h}$. The reaction mixture was precipitated dropwise into THF (150 $\mathrm{mL}$ ) and the precipitate was isolated via centrifugation. The precipitate was re-dissolved in Milli-Q water $(10 \mathrm{~mL})$ and precipitated into THF (200 $\mathrm{mL})$. The precipitate was collected by centrifugation, redissolved in Milli-Q water $(25 \mathrm{~mL})$ and lyophilized to afford macroinitiator $\mathbf{P}_{\mathbf{I n i}}$ as a light yellow solid, $629 \mathrm{mg}$ (47\%). Quantitative quaternization of the amino groups was confirmed by ${ }^{1} \mathrm{H}-\mathrm{NMR}$ spectroscopy. GPC (aqueous): $M_{\mathrm{n}}=15100 \mathrm{~g} \cdot \mathrm{mol}^{-1}, M_{\mathrm{w}}=19400$ g.mol ${ }^{-1}, Ð=1.28 .{ }^{1} \mathrm{H}$ NMR (400 MHz, DMSO-d6, $25{ }^{\circ} \mathrm{C}$ ): $\delta_{\mathrm{H}}$ $(\mathrm{ppm})=4.37\left(\mathrm{~m}, 4 \mathrm{H}, \mathrm{CH}_{2} \mathrm{OC}(=\mathrm{O})\left(\mathrm{CH}_{3}\right)_{2} \mathrm{Br}\right.$ and $\mathrm{CH}_{2} \mathrm{~N}^{+} \mathrm{I}$ $\left.\left(\mathrm{CH}_{3}\right)_{3}\right), 4.16\left(\mathrm{~m}, 2 \mathrm{H}, \mathrm{O}=\mathrm{COCH}_{2}\right), 3.84\left(\mathrm{~m}, 2 \mathrm{H}, \mathrm{O}=\mathrm{COCH}_{2}\right)$, 3.46-3.14 (br s, 9H, $\left.\mathrm{CH}_{2} \mathrm{~N}^{+} \mathrm{I}^{-}\left(\mathrm{CH}_{3}\right)_{3}\right), 1.93$ (br s, 6H, $\left.\mathrm{OC}(=\mathrm{O})\left(\mathrm{CH}_{3}\right)_{2} \mathrm{Br}\right), 2.14-1.70\left(\mathrm{~m}, 2 \mathrm{H}, \mathrm{CH}_{2} \mathrm{C}\left(\mathrm{CH}_{3}\right) \mathrm{C}=0\right)$, 1.18$0.70\left(\mathrm{~m}, 3 \mathrm{H}, \mathrm{CH}_{2} \mathrm{C}\left(\mathrm{CH}_{3}\right) \mathrm{C}=0\right)$.

CAP $_{\text {ATRP }}$ Reactions on Planar Substrates. The substrate was initially surface-functionalized with bromoester initiators prior to $\mathrm{CAP}_{\text {ATRP. Typically, hyperbranched PEI was }}$ deposited onto the substrate, followed by PSS and the macroinitiator $\mathbf{P}_{\text {Ini }}$ using electrostatic interactions. The negatively charged Si wafer was added to a glass vial $(7 \mathrm{~mL})$ containing a solution of PEI $\left(1 \mathrm{mg} \cdot \mathrm{mL}^{-1}\right.$ in $0.5 \mathrm{M} \mathrm{NaCl}, 1$ $\mathrm{mL}$ ) incubated for $20 \mathrm{~min}$ at $25^{\circ} \mathrm{C}$. The wafer was thoroughly washed with Milli-Q water $(3 \times 20 \mathrm{~mL})$ and dried under a flow of Ar. PSS ( $1 \mathrm{mg} \cdot \mathrm{mL}^{-1}$ in $0.5 \mathrm{M} \mathrm{NaCl}, 1 \mathrm{~mL}$ ) and then $\mathbf{P}_{\text {Ini }}$ ( 2 mg.mL $\mathrm{mL}^{-1}$ in $0.5 \mathrm{M} \mathrm{NaCl}, 1 \mathrm{~mL}$ ) were sequentially deposited onto the Si wafer in an identical fashion to the PEI immobilization step.

The $\mathrm{CAP}_{\text {ATRP }}$ was conducted under activator regenerated by electron transfer (ARGET) ${ }^{39}$ conditions in Milli-Q water at ambient temperature. In a typical experiment, a Si wafer functionalized with macroinitiator $\mathbf{P}_{\text {Ini }}$ was added to an aqueous solution containing macrocross-linker P2 (40 mg in $700 \mu \mathrm{L}$ Milli-Q water) in a glass vial $(7 \mathrm{~mL})$. Aqueous stock solutions of $\mathrm{CuBr}_{2}$ : $\mathrm{Me}_{6}$ TREN (10:30 mM, $\left.100 \mu \mathrm{L}\right)$ and sodium ascorbate $(100 \mathrm{mM}, 200 \mu \mathrm{L})$ were added, the vial was sealed, and the mixture was incubated at $25{ }^{\circ} \mathrm{C}$ for 20 h. The Si wafer was washed with Milli-Q water $(3 \times 20 \mathrm{~mL})$, 
soaked in water $(20 \mathrm{~mL})$ for $1 \mathrm{~h}$, and then air dried prior to analysis.

For CAPATRP with the micellar form of macrocross-linker P1, the diblock copolymer (20 mg) was first dissolved in DMF (50 $\mu \mathrm{L})$ before slowly being diluting with Milli-Q water $(650 \mu \mathrm{L})$. A macroinitiator PIni functionalized Si wafer was then added to the micellar solution followed by the addition of catalyst and ascorbate stock solutions as described previously. For CAPATRP with the macrocross-linker P1 as a linear diblock copolymer (and not as micelles), Milli-Q water and sodium ascorbate were replaced with DMF and phenylhydrazine as the solvent and reducing agent, respectively. All other conditions proceeded in ex-

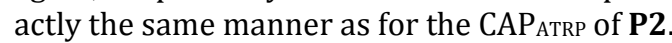

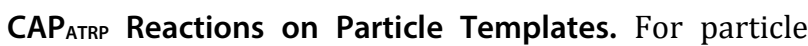
templates the surface was functionalized with macroinitiator $\mathbf{P}_{\mathbf{I n i}}$ in a similar fashion to that described for planar substrates. The particle suspension $\left(\mathrm{SiO}_{2}, 0.5 \mathrm{wt} \%\right.$ in water, $1 \mathrm{~mL}$ ) was first centrifuged and the supernatant decanted. The particles were then incubated in a PEI solution ( $1 \mathrm{mg} . \mathrm{mL}^{-1}$ in $0.5 \mathrm{M} \mathrm{NaCl}, 1 \mathrm{~mL}$ ) for $20 \mathrm{~min}$ at $25^{\circ} \mathrm{C}$, isolated by centrifugation and washed with Milli $Q$ water $(3 \times 1$ $\mathrm{mL}$ ). PSS (1 mg.mL $\mathrm{mL}^{-1}$ in $0.5 \mathrm{M} \mathrm{NaCl}, 1 \mathrm{~mL}$ ) and then $\mathbf{P}_{\mathbf{I n i}}(2$ mg.mL ${ }^{-1}$ in $0.5 \mathrm{M} \mathrm{NaCl}, 1 \mathrm{~mL}$ ) were sequentially deposited onto the particles in an identical fashion to the PEI immobilization step.

A micellar macrocross-linker P1 solution $(20 \mathrm{mg}$ in 700 $\mu \mathrm{L})$ with encapsulated Nile Red dye was prepared. The macrocross-linker P1 (20 mg) was dissolved in a solution of Nile Red $(0.1 \mathrm{mg}$ in $50 \mu \mathrm{L}$ in DMF) followed by the dropwise addition of Milli-Q water $(650 \mu \mathrm{L})$. The solution was centrifuged and the purple supernatant was isolated from any nonsolubilized hydrophobic dye. The loading of the dye was determined to be $95 \%$ based on UV absorbance measurements (see Figure S1 of the Supporting Information (SI)). Macroinitiator $\mathbf{P}_{\text {Ini-functionalized particles }}$ were then dispersed in the freshly prepared micellar P1 solution with encapsulated dye. Aqueous stock solutions of $\mathrm{CuBr}_{2}$ :Me $\mathrm{MREN}_{6}(10: 30 \mathrm{mM}, 100 \mu \mathrm{L})$ and sodium ascorbate $(100 \mathrm{mM}, 200 \mu \mathrm{L})$ were then added and the mixture was incubated with agitation at $208 \mathrm{~g}$ (Thermomixer Comfort, Eppendorf) at $25{ }^{\circ} \mathrm{C}$ for $20 \mathrm{~h}$. Subsequently, the particles were isolated by centrifugation, washed with Milli-Q water $(3 \times 1 \mathrm{~mL})$ and $\mathrm{MeOH}(3 \times 1 \mathrm{~mL})$, and then soaked in water $(1 \mathrm{~mL})$ for $1 \mathrm{~h}$ prior to analysis.

\section{RESULTS AND DISCUSSION}

One of the prerequisites to conduct a CAP process is the synthesis of preformed macrocross-linkers. A three-step synthetic strategy was employed to obtain the desired amphiphilic diblock copolymer macrocross-linker P1 (polystyrene- $b$-poly[( $N$-(2-hydroxypropyl) methacrylamide)ran-( $N$-(2-(acryloxy)propyl)methacrylamide)]) that can self-assemble in aqueous solution to form micelles. RAFT was chosen as the polymerization method to synthesize P1 as a result of the versatility of this technique to polymerize a wide range of monomers, including electron-deficient (methacrylamide) and electron-rich (styrene) monomers. In addition, PHPMA was selected as a part of the P1 mac- rocross-linker as a result of its excellent biocompatibility and hydrophilicity. ${ }^{40}$

Firstly, the hydrophobic polystyrene (PS) block was prepared via RAFT polymerization using the dithiobenzoate, $\mathrm{CPAD}$, as the chain transfer agent. The polymerization was well-controlled, providing PS with a narrow molecular weight distribution (dispersity $(Đ)=1.05$ ) and numberaverage molecular weight $\left(M_{\mathrm{n}}\right)$ of $10200 \mathrm{~g} \cdot \mathrm{mol}^{-1}$, as determined by GPC (Figure 1a). The PS macroRAFT agent was chain extended with $N$-(2-hydroxypropyl)methacrylamide (HPMA) to afford the amphiphilic diblock copolymer, polystyrene- $b$-poly( $N$-(2-hydroxypropyl)methacrylamide) (PS$b$-PHPMA). At the end of the second RAFT reaction, the RAFT end-group was intentionally cleaved via one-pot aminolysis with hexylamine and the resulting thiol was capped via thiol-Michael addition ${ }^{41,42}$ with maleimide to prevent any undesired side-reactions during the $\mathrm{CAP}_{\mathrm{ATRP}}$ process. The reaction was deemed complete upon a change in color of the polymerization mixture from bright red to light orange. GPC of the PS- $b$-PHPMA (Figure 1a) confirmed the successful chain extension with a shift in the differential refractive index (DRI) distribution of the PS macroRAFT agent towards lower retention times. The $M_{\mathrm{n}}$ and $Ð$ values of the PS- $b$-PHPMA were determined to be 30100 g.mol ${ }^{-1}$ and 1.40, respectively. The chain extended product exhibited a symmetrical and monomodal molecular weight distribution, even though the $Ð$ of the PS- $b$ PHPMA was larger than that of the PS (1.40 vs. 1.05). Surprisingly, the increase in $M_{\mathrm{n}}$ of 19900 g.mol $^{-1}$ (from 10200 to 30100 g.mol-1), which amounts to $c a .139$ repeat units of HPMA, is actually double the theoretical value (based on the molar ratio used). A possible explanation for this may be the slow establishment of the RAFT equilibrium, resulting in less effective (but sufficient) control over the propagating radicals, especially given the fact that a dithiobenzoate RAFT agent was used instead of a trithiocarbonate derivative, which are known to better mediate the controlled polymerization of (meth)acrylamides. This would also explain the broader than expected molecular weight distribution of the PS- $b$-PHPMA. In completing the synthesis of the macrocross-linker P1, the hydroxyl groups of the PHPMA block of PS- $b$-PHPMA were partially converted to acrylate moieties, via esterification with acryloyl chloride. GPC of $\mathbf{P 1}$ revealed a symmetrical and narrow molecular weight distribution $\left(M_{\mathrm{n}}=32700 \mathrm{~g} \cdot \mathrm{mol}^{-1}\right.$ and $\left.Ð=1.40\right)$ (Figure 1a), thereby suggesting that the esterification reaction did not cause unwanted side reactions such as transesterification. 
a)

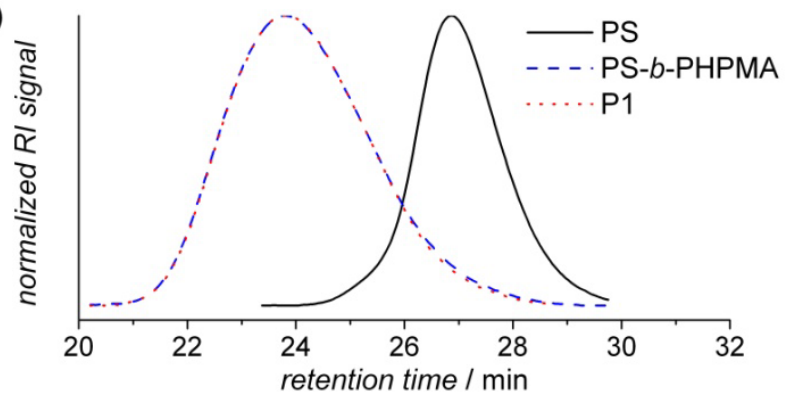

b)

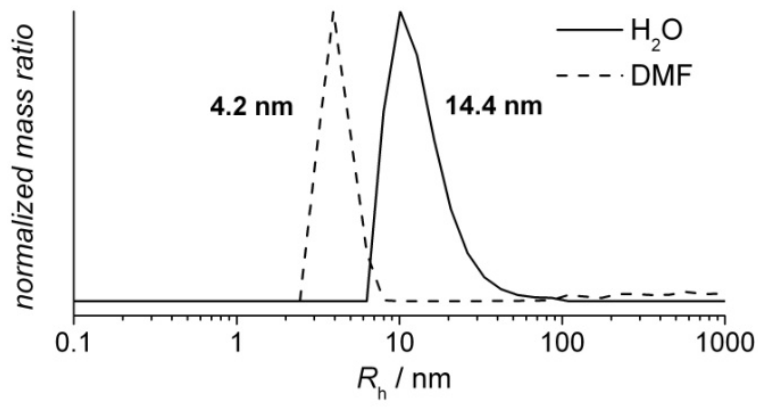

Figure 1. (a) GPC DRI chromatograms of the RAFT-derived polystyrene (PS), chain extended diblock copolymer, polystyrene- $b$-poly $(N$-(2-hydroxypropyl) methacrylamide) (PS- $b$ PHPMA), and macrocross-linker P1. (b) DLS normalized mass ratio of P1 in different solvents (at a concentration of 0.1 $\left.\mathrm{mg} \cdot \mathrm{mL}^{-1}\right)$ as a function of hydrodynamic radius $\left(R_{\mathrm{h}}\right)$.

The step-by-step synthesis of P1 was monitored concurrently by ${ }^{1} \mathrm{H}$ NMR spectroscopy (Figure 2). The PS macroRAFT agent displayed characteristic resonances corresponding to the alkyl backbone protons and aromatic protons (resonances a and b, $\delta_{\mathrm{H}} 2.10-1.10 \mathrm{ppm}$; and resonances c and $\mathrm{d}, \delta_{\mathrm{H}} 7.20-6.30 \mathrm{ppm}$, respectively). Following chain extension, resonances corresponding to the methine (resonance $\mathrm{f}, \delta_{\mathrm{H}} 3.75-3.52 \mathrm{ppm}$ ) and hydroxyl protons (resonance $\mathrm{g}, \delta_{\mathrm{H}} 4.78-4.60 \mathrm{ppm}$ ) of the 2-hydroxypropyl groups of the HPMA repeat units are clearly visible, confirming the presence of PHPMA. The molar ratio of styrene to HPMA repeat units was calculated to be $c a$. 1:1.2, which is in good agreement with the data obtained by GPC ( $c a$. 1:1.4). Furthermore, the successful aminolysis of the RAFT end-group was also confirmed by the disappearance of resonances corresponding to the dithiobenzoate group at $\delta_{\mathrm{H}} 7.80 \mathrm{ppm}$. The partial convesion of the hydroxyl groups of the PS- $b$-PHPMA to acrylates (ca. 9\%) was also confirmed by ${ }^{1} \mathrm{H}$ NMR spectroscopic analysis, with the appearance of characteristic resonances corresponding to acrylate groups (resonances $\mathrm{h}, \mathrm{i}$ and $\mathrm{j}, \delta_{\mathrm{H}} 6.36-5.82 \mathrm{ppm}$ ). The combination of GPC and NMR analysis provide good evidence for the chemical structure of the targeted macrocross-linker P1.

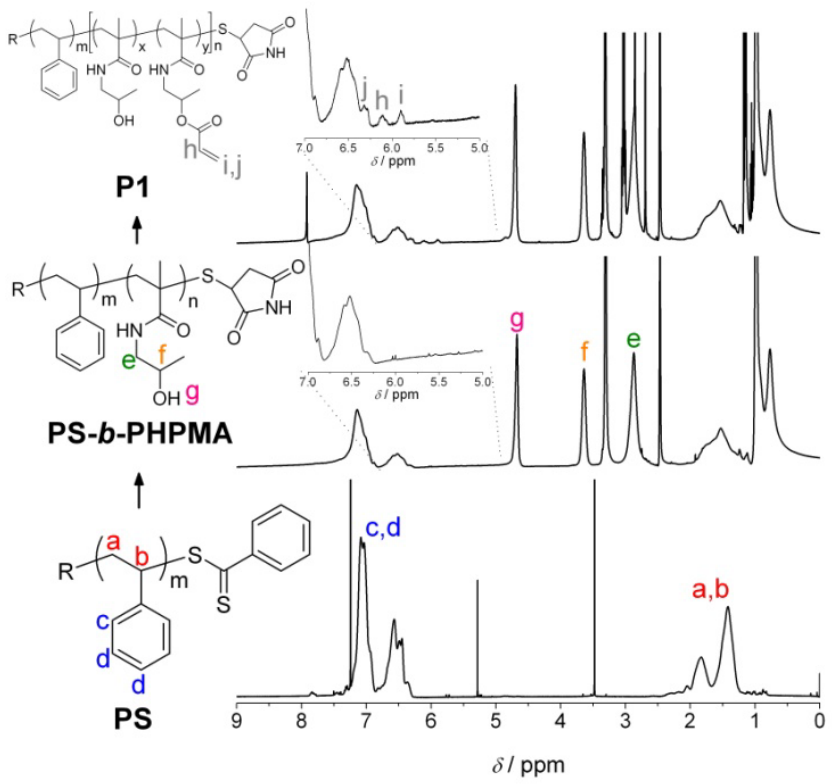

Figure 2. ${ }^{1} \mathrm{H}$ NMR spectra of the PS macroRAFT agent, PS$b$-PHPMA and the macrocross-linker P1. The resonances that correspond to the key functional groups of these polymers are labeled. The R-group refers to the initiating moiety, 4-cyanopentanoic acid.

The ability of P1 to self-assemble in aqueous solution was investigated using DLS. To induce micelle formation, P1 was first dissolved in a minimal amount of good solvent (DMF) for both blocks (at a concentration of $400 \mathrm{mg} \cdot \mathrm{mL}^{-1}$ ), followed by dilution with Milli-Q water to afford a final concentration of $20 \mathrm{mg} \cdot \mathrm{mL}^{-1}$. The micellar solution of P1 was further diluted with Milli-Q water to a concentration of $0.1 \mathrm{mg} . \mathrm{mL}^{-1}$ for DLS analysis. The P1 micelles were found to have a mean hydrodynamic radius $\left(R_{\mathrm{h}}\right)$ of $14.4 \mathrm{~nm}$ in aqueous solution (Figure 1b). Under non-micelle forming conditions (i.e., in DMF), the $R_{\mathrm{h}}$ of the linear diblock copolymer P1 was only $4.2 \mathrm{~nm}$ (Figure $1 \mathrm{~b}$ ). Based on the DLS results, it can be confirmed that $\mathbf{P 1}$ forms micelles in an aqueous environment.

Generally, in a CAP process, the initiator-functionalized substrates are exposed to a solution of macrocross-linkers, which results in the polymerization of the macrocrosslinkers from the surface while forming cross-linked nanoscale films. To examine the feasibility of employing micellar-based macrocross-linkers in the CAP processes, the assembled $\mathbf{P 1}$ micelles were subjected to $\mathrm{CAP}_{\text {ATRP }}$ reactions from bromoester-functionalized Si wafers. A thin film (in the dehydrated state) with a mean thickness of $15.2 \mathrm{~nm}$ (including $3.8 \mathrm{~nm}$ of initiator prelayer) was formed (Table 1), as determined by AFM. For comparison, films were also prepared with the linear PHPMA homopolymer macrocross-linker P2 $\left(M_{\mathrm{n}}=31500\right.$ g.mol-1) that was functionalized with a similar percentage of polymerizable acrylate groups ( $c$. 10\%). The micellar films derived from $\mathbf{P 1}$ were on average $5 \mathrm{~nm}$ thicker than those prepared from the linear analogue $\mathbf{P 2}$, which is not surprising given that the micelles occupy a larger hydrodynamic volume compared to the linear analogue $\left(R_{\mathrm{h}}=2.4 \mathrm{~nm}\right)$ (Figure S2 in SI), and as such might be expected to produce thicker films. De- 
spite both surfaces having identical surface roughness (as indicated by the root mean square (rms) values) of $1.6 \mathrm{~nm}$, the dehydrated micellar films possess distinguishable pitted morphologies (Figure 3a) compared to the smooth flat surfaces obtained using linear polymers, comparable to earlier studies (Figure $3 \mathrm{~b}$ ). ${ }^{27-30}$ The observation of pitted morphologies is similar to reported literature where core cross-linked star polymers were used in the assembly of thin films via the LbL method. ${ }^{15}$ To validate if the pitted morphology is distinctive to micellar films, an additional experiment was performed using P1 in CAPATRP under nonmicelle forming conditions (i.e., DMF solvent). In this case, the surface topography is neither pitted nor flat, but instead resembles that of small granules (Figure 3c). Moreover, the films were coarse and rough $(\mathrm{rms}=3.3 \mathrm{~nm})$, and also thinner $(7.5 \mathrm{~nm})$ than both the P1 micellar and P2 linear polymer films. It is likely that the hydrophobic PS blocks - under non-micelle forming conditions - have a higher degree of flexibility to reptate away from the hydrophilic surface of the substrate, which in turn leads to protruded PS chains on the surface, creating granular topographies. Whereas in the micellar state, the PS blocks are confined to the cores of the micelles and are therefore less likely to undergo reptation, especially when the hydrophilic PHPMA shells of the micelles are cross-linked in situ, consequently locking the core-shell conformation in place during the film formation process. In addition, given that the polymerizable acrylate groups are not attached to the PS blocks, the hydrophobic segments are unable to undergo cross-linking. As micelles, this should not affect the propagation step in the CAP process so long as the outer shells of the micelles are sufficiently functionalized with polymerizable groups, and that the PS chains are confined to the core and the micelles remain stable throughout the polymerization step. In contrast, when the assembly is conducted in DMF, the presence of non-polymerizable PS blocks could hinder film propagation by forming steric barriers that limit the reaction of propagating radicals on the surface with the pendent acrylate groups on diblock copolymers in solution near the surface. This accounts for the observed lower film thickness when a linear diblock copolymer composed of polymerizable and nonpolymerizable blocks, such as $\mathbf{P 1}$, is applied in CAP reactions. From the AFM results, it is deduced that the surface morphology, thickness and roughness of CAP films are tunable by simply varying the architecture of macrocrosslinkers.

Table 1. Film Thicknesses and Surface Roughness Val-

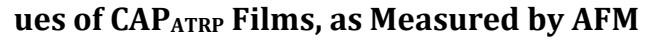

\begin{tabular}{llcc}
\hline Entry & Macrocross-linker $^{a}$ & $\begin{array}{c}\text { Thickness }^{b} \\
\mathrm{~nm}\end{array}$ & $\begin{array}{c}\text { rms } \\
\mathrm{nm}\end{array}$ \\
\hline 1 & P1 micelle (aq) & $15.2 \pm 1.1$ & 1.6 \\
$2^{c}$ & P1 micelle (aq) & $10.1 \pm 1.6$ & 2.2 \\
3 & P2 linear (aq) & $10.2 \pm 1.1$ & 1.6 \\
$4^{c}$ & P2 linear (aq) & $10.0 \pm 1.5$ & 2.3 \\
5 & P1 linear diblock (org) & $7.5 \pm 1.9$ & 3.3 \\
$6^{c}$ & P1 linear diblock (org) & $5.0 \pm 1.0$ & 1.6 \\
\hline
\end{tabular}

${ }^{a}$ The solvents employed in the CAPATRP reactions are indicated in brackets (aq = aqueous; org = DMF).

$b$ Values represent the mean of at least five measurement areas along the scratch profile. The measured film thicknesses of the CAP films are inclusive of $3.8 \pm 0.7 \mathrm{~nm}$ resulting from the initiator prelayer.

${ }^{c}$ After thermal annealing.

A better understanding of the film properties was obtained after thermally annealing the formed CAP films in vacuo at $150{ }^{\circ} \mathrm{C}$ for $24 \mathrm{~h}$. The annealed films were analyzed by AFM (Table 1 and Figure 3d-f). Whereas the thicknesses of both the P1 micellar and linear diblock copolymer films decreased by $c a$. 33\%, the thickness of the homopolymer P2 film remained constant (Table 1). Since the annealing temperature is above the glass transition temperature $\left(T_{\mathrm{g}}\right)$ of PS, the noncross-linked PS segments (although still covalently tethered to the cross-linked PHPMA network) can rearrange themselves, leading to thinner and possibly more densely packed films. This can occur if parts of the films are not cross-linked. For films that are fully or highly cross-linked, as in the case of $\mathbf{P 2}$ films, rearrangement of the polymer chains is not possible even if the film is annealed above its $T_{\mathrm{g}}$. This observation is in line with our earlier study where cross-linked linear polymer CAP films did not exhibit any obvious reduction in film thickness after thermal annealing. ${ }^{27}$ In terms of surface morphology, P1 micellar and P2 linear polymer films maintained similar pitted and smooth morphologies, respectively (Figure $3 \mathrm{~d}$ and e, respectively). However, the surface morphology of films prepared from the linear diblock copolymer P1 changed from granular-like to smooth after thermal annealing (Figure 3f). Although both the P1 micellar and linear diblock copolymer films contain noncross-linked PS chains, their film conformations differ from one another. In the micellar films, the PS segments are compartmentalized within the films, and surrounded by the cross-linked PHPMA exterior as a result of the core-shell architecture of the micelles. Therefore, even though hydrophobic PS and hydrophilic PHPMA would be expected to phase separate in the solid state above their $T_{\mathrm{g}}$, the mobility of PS chains would still be confined within their hydrophobic compartments. As such, the integrity of the pitted morphology of P1 micellar films remained intact. On the other hand, the noncompartmentalized and collapsed PS chains in the linear diblock copolymer films relax upon annealing and move around to spread across the surface and interact with one another. This results in the observed change in surface morphology of the P1 linear diblock copolymer films after thermal annealing. Since P2 films are highly cross-linked and do not possess any PS segments, the lack of surface topographical changes observed is expected. The effect of soaking the CAP films in DMF (which is a good solvent for both PS and PHPMA segments) was also investigated and the DMF-soaked films were analyzed by AFM (Figure S3 (a-c)). No surface morphological changes were observed with the P2 linear and P1 linear diblock copolymer films after soaking in DMF. However, the pitted morphology of P1 micellar films became less pronounced. Unlike the thermally annealed films, P1 micellar films are 
solvated when soaked in DMF, therefore causing the PS and PHPMA segments to intermix rather than phase sepa- rate, which ultimately result in the loss of core-shell structure and pitted morphology.
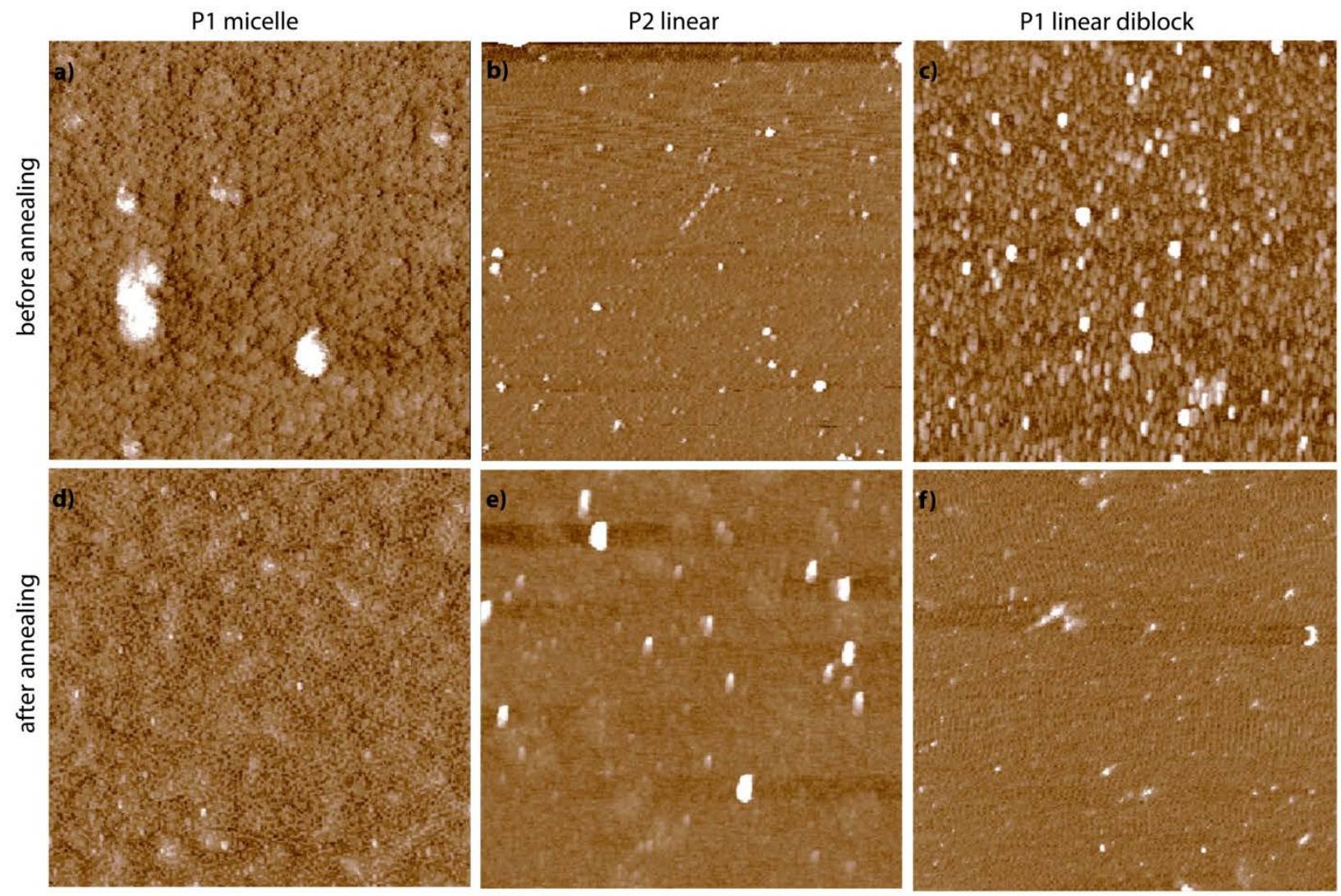

Figure 3. 3D height mode AFM images $(5 \times 5 \mu \mathrm{m})$ of air-dried films prepared by CAPATRP before (a-c) and after (d-f) thermal annealing. The AFM images correspond to the various structures of macrocross-linkers that have been employed in CAPATRP, including ( $a$ and d) the micellar form of P1, (b and e) linear P2, and (c and f) linear diblock copolymer P1.

Water contact angle analysis was also performed on the films to further investigate the surface properties. If the P1 micellar film possess the core-shell architecture of the precursors, the outermost layer of the CAP film will be the hydrophilic PHPMA shell and the contact angle of water droplets on the micellar films will be similar to that on P2 films. As predicted, the water contact angle of $\mathbf{P 1}$ micellar and P2 linear polymer films $\left(38^{\circ}\right)$ are identical (Figure $4 \mathrm{a}$ and $b$, respectively). In contrast, the water contact angle on P1 linear diblock copolymer films $\left(60^{\circ}\right)$ is higher compared to the other films, indicating that the surface is more hydrophobic (Figure 4c). This also supports the hypothesis that the noncross-linked PS chains in P1 linear diblock copolymer films are protruding out from the surface, unlike in the $\mathbf{P 1}$ micellar films where the PS segments are confined in the micelle core. Water contact angle analysis on DMF-soaked films indicated an increase in surface hydrophobicity for P1 micellar films (62) (Figure 4d) whereas the water contact angles on both P2 linear and P1 linear diblock copolymer films displayed only minor changes (Figure $4 \mathrm{e}$ and $\mathrm{f}, 43^{\circ}$ and $55^{\circ}$, respectively). As the P1 micellar films are solvated in DMF, the PS chains are able to migrate and protrude from the surface, thereby forming a more hydrophobic layer. This also supports the change in surface morphology observed in the AFM images.

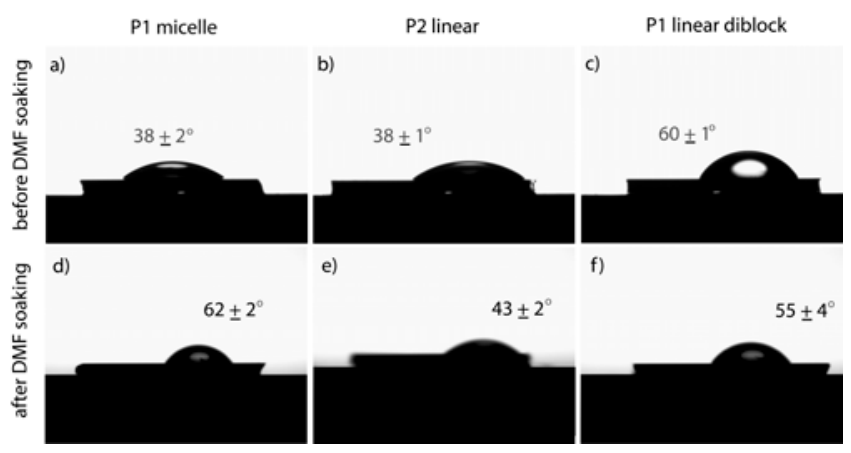

Figure 4. Water contact angle measurements on $\mathrm{CAP}_{\mathrm{ATRP}}$ films before (a-c) and after soaking in DMF (d-f).

CAP $_{\text {ATRP }}$ using micellar macrocross-linkers was also successfully applied on particle templates. Nonporous $\mathrm{SiO}_{2}$ particles with an average diameter of $3 \mu \mathrm{m}$ were prefunctionalized with the ATRP macroinitiator $\mathbf{P}_{\text {Ini. The }}$ $\mathrm{CAP}_{\text {ATRP }}$ reactions were performed in the same way as that described for the Si wafers, except that the P1 micelles were preloaded with the dye Nile Red. Nile Red is extremely hydrophobic and exhibits fluorescence in hydrophobic 
environments, such as organic solvents or in the PS cores of P1 micelles. Figure 5a compares the encapsulation of Nile Red in an aqueous solution of hydrophilic PHPMA P2 and P1 micellar macrocross-linkers. In an aqueous solution of P2, the hydrophobic dye appears to be insoluble and coats the vessel walls of the Eppendorf tube (Figure $5 \mathrm{a}$ - left). Noteworthy, Nile Red (0.1 mg) was initially soluble in a solution of DMF containing P2 $(50 \mu \mathrm{L})$ but precipitated upon the addition of water $(650 \mu \mathrm{L})$. In comparison, when a P1 micellar solution was used the dye was successfully encapsulated in the hydrophobic cores of the micelles, as indicated by the immediate formation of a fluorescent dark purple solution (Figure 5a - right). Once the ability of the micelles to encapsulate hydrophobic molecules was confirmed, the 'loaded' P1 micellar macrocross-linkers were assembled onto initiator-functionalized $\mathrm{SiO}_{2}$ particles via

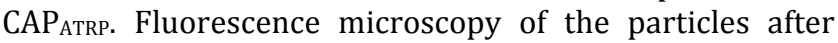
CAP revealed the formation of fluorescently labeled particles as a result of the incorporation of Nile Red into the hydrophobic compartments of the micellar films (Figure $5 b)$. This provides further evidence that the micellar structure is maintained within the film.

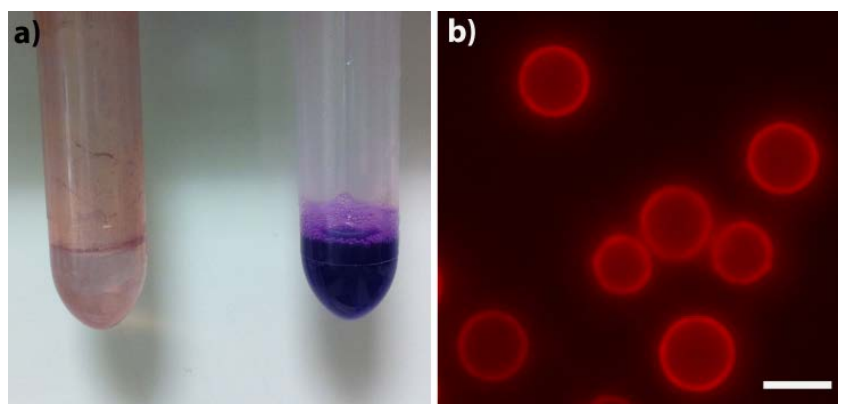

Figure 5. (a) Encapsulation of hydrophobic dye, Nile Red, in aqueous solutions of linear PHPMA P2 (left) and P1 micellar macrocross-linkers (right). (b) Fluorescence microscopy images of $\mathrm{SiO}_{2}$ particles coated with CAP films made using P1 micellar macrocross-linkers preloaded with Nile Red. Scale bar is $3 \mu \mathrm{m}$.

\section{CONCLUSION}

A novel macrocross-linker, P1, derived from polystyrene- $b$-poly( $N$-(2-hydroxypropyl)methacrylamide) was synthesized via RAFT polymerization. The macrocrosslinker, which possessed a narrow and monomodal molecular weight distribution, was self-assembled in aqueous solution to afford uniform micelles with a mean hydrodynamic radius of $14.4 \mathrm{~nm}$. The efficacy of $\mathbf{P 1}$ micelles as macrocross-linkers in the CAPATRP process was then demonstrated. Surface coatings with pitted surface morphology unique to micellar macrocross-linkers were obtained, as evidenced by AFM analysis. In addition, the PS core of the micelles was utilized to encapsulate hydrophobic molecules, thus allowing cargo loading and segregation within the compartmentalized micellar films. This study serves as a promising platform for the synthesis of advanced materials with complex and hierarchically structured cross-linked films. Work is currently underway to utilize CAP to prepare a range of nanostructured films from complex macromolecular architectures for targeted biological and sensing applications.

\section{ASSOCIATED CONTENT}

\section{Supporting Information}

Additional data including UV-Vis correlation plots, DLS analysis, and AFM images and z-profile of scratched films. This material is available free of charge via the Internet at http://pubs.acs.org.

\section{AUTHOR INFORMATION}

\section{Corresponding Authors}

*Email: gregghq@unimelb.edu.au; fcaruso@unimelb.edu.au.

\section{Present Addresses}

†Mawson Institute, University of South Australia, Adelaide, South Australia 5095, Australia.

Notes

The authors declare no competing financial interest.

\section{ACKNOWLEDGMENT}

The authors acknowledge the Australian Research Council under the Australian Laureate Fellowship (FL120100030, F.C.), Future Fellowship (FT110100411, G.G.Q.) and Discovery Project (DP1094147 and DP130101846, F.C., G.G.Q.) schemes for financial support of this work.

\section{REFERENCES}

(1) Ma, N.; Zhang, H.; Song, B.; Wang, Z.; Zhang, X. Chem. Mater. 2005, 17, 5065.

(2) Zhu, Z.; Sukhishvili, S. A. J. Mater. Chem. 2012, 22, 7667.

(3) Nguyen, P. M.; Zacharia, N. S.; Verploegen, E.; Hammond, P. T. Chem. Mater. 2007, 19, 5524 .

(4) Qi, B.; Tong, X.; Zhao, Y. Macromolecules 2006, 39, 5714.

(5) Webber, G. B.; Wanless, E. J.; Butun, V.; Armes, S. P.; Biggs, S. Nano Lett. 2002, 2, 1307.

(6) Ouhib, F.; Desbief, S.; Lazzaroni, R.; Melinte, S.; Dutu, A.; Jerome, C.; Detrembleur, C. Polym. Chem. 2013, 4, 4151.

(7) Gensel, J.; Betthausen, E.; Hasenohrl, C.; Trenkenschuh, K.; Hund, M.; Boulmedais, F.; Schaaf, P.; Muller, A. H. E.; Fery, A. Soft Matter 2011, 7, 11144.

(8) Kim, B.-S.; Gao, H.; Argun, A. A.; Matyjaszewski, K.; Hammond, P. T. Macromolecules 2009, 42, 368.

(9) Heise, A.; Nguyen, C.; Malek, R.; Hedrick, J. L.; Frank, C. W.; Miller, R. D. Macromolecules 2000, 33, 2346.

(10) Kanibolotsky, A. L.; Perepichka, I. F.; Skabara, P. J. Chem. Soc. Rev. 2010, 39, 2695.

(11) Cha, H.; Chung, D. S.; Bae, S. Y.; Lee, M.-J.; An, T. K.; Hwang, J.; Kim, K. H.; Kim, Y.-H.; Choi, D. H.; Park, C. E. Adv. Funct. Mater. 2013, 23, 1556 .

(12) van de Craats, A. M.; Warman, J. M.; Fechtenkotter, A.; Brand, J. D.; Harbison, M. A.; Mullen, K. Adv. Mater. 1999, 11, 1469.

(13) Cremer, J.; Bauerle, P. J. Mater. Chem. 2006, 16, 874.

(14) Nguyen, C. V.; Carter, K. R.; Hawker, C. J.; Hedrick, J. L.; Jaffe, R. L.; Miller, R. D.; Remenar, J. F.; Rhee, H.-W.; Rice, P. M.; Toney, M. F.; Trollsas, M.; Yoon, D. Y. Chem. Mater. 1999, 11, 3080.

(15) Connal, L. A.; Li, Q.; Quinn, J. F.; Tjipto, E.; Caruso, F.; Qiao, G. G. Macromolecules 2008, 41, 2620.

(16) Chuang, Y.-M.; Jack, K. S.; Cheng, H.-H.; Whittaker, A. K.; Blakey, I. Adv. Funct. Mater. 2013, 23, 173.

(17) Chandrawati, R.; Odermatt, P. D.; Chong, S.-F.; Price, A. D.; Stadler, B.; Caruso, F. Nano Lett. 2011, 11, 4958. 
(18) Chandrawati, R.; Hosta-Rigau, L.; Vanderstraaten, D.; Lokuliyana, S. A.; Städler, B.; Albericio, F.; Caruso, F. ACS Nano 2010, 4, 1351.

(19) Shen, L.; Hu, N. Biomacromolecules 2005, 6, 1475.

(20) Wong, W. W. H.; Ma, C.-Q.; Pisula, W.; Yan, C.; Feng, X.; Jones, D. J.; Mullen, K.; Janssen, R. A. J.; Bauerle, P.; Holmes, A. B. Chem. Mater. 2010, 22, 457.

(21) Decher, G. Science 1997, 277, 1232.

(22) Quinn, J. F.; Johnston, A. P. R.; Such, G. K.; Zelikin, A. N.; Caruso, F. Chem. Soc. Rev. 2007, 36, 707.

(23) Olivier, A.; Meyer, F.; Raquez, J.-M.; Damman, P.; Dubois, P. Prog. Polym. Sci. 2012, 37, 157.

(24) Li, B.; Yu, B.; Huck, W. T. S.; Zhou, F.; Liu, W. Angew. Chem. Int. Ed. 2012, 51, 5092.

(25) Huang, L.; Dolai, S.; Raja, K.; Kruk, M. Langmuir 2010, 26 , 2688.

(26) Pauloehrl, T.; Delaittre, G.; Winkler, V.; Welle, A.; Bruns, M.; G. Borner, A. M. Greiner, M. Bastmeyer and C. Barner-Kowollik, H. Angew. Chem. Int. Ed. 2012, 51, 1071.

(27) Goh, T. K.; Guntari, S. N.; Ochs, C. J.; Blencowe, A.; Mertz, D.; Connal, L. A.; Such, G. K.; Qiao, G. G.; Caruso, F. Small 2011, 7, 2863.

(28) Mertz, D.; Ochs, C. J.; Zhu, Z.; Lee, L.; Guntari, S. N.; Such, G. K.; Goh, T. K.; Connal, L. A.; Blencowe, A.; Qiao, G. G.; Caruso, F. Chem. Commun. 2011, 47, 12601.

(29) Wong, E. H. H.; Guntari, S. N.; Blencowe, A.; van Koeverden, M. P.; Caruso, F.; Qiao, G. G. ACS Macro Lett. 2012, 1, 1020.
(30) Guntari, S. N.; Goh, T. K.; Blencowe, A.; Wong, E. H. H.; Caruso, F.; Qiao, G. G. Polym. Chem. 2012, 4, 68.

(31) Guntari, S. N.; Khin, A. C. H.; Wong, E. H. H.; Goh, T. K.; Blencowe, A.; Caruso, F.; Qiao, G. G. Adv. Funct. Mater. 2013, DOI: 10.1002/adfm.201300768.

(32) Matyjaszewski, K.; Xia, J. H. Chem. Rev. 2001, 101, 2921.

(33) Matyjaszewski, K. Isr. J. Chem. 2012, 52, 206.

(34) Beers, K. L.; Boo, S.; Gaynor, S. G.; Matyjaszewski, K. Macromolecules $1999,32,5772$.

(35) Queffelec, J.; Gaynor, S. G.; Matyjaszewski, K. Macromolecules 2000, 33, 8629 .

(36) Moad, G.; Rizzardo, E.; Thang, S. H. Aust. J. Chem. 2005, 58, 379 .

(37) Moad, G.; Rizzardo, E.; Thang, S. H. Aust. J. Chem. 2009, 62, 1402.

(38) Greene, A. C.; Zhu, J.; Pochan, D. J.; Jia, X.; Kiick, K. L. Macromolecules 2011, 44, 1942.

(39) Matyjaszewski, K.; Dong, H.; Jakubowski, W.; Pietrasik, J.; Kusumo, A. Langmuir 2007, 23, 4528.

(40) Williams, C. C.; Thang, S. H.; Hantke, T.; Vogel, U.; Seeberger, P. H.; Tsanaktsidis, J.; Lepenies, B. Chem. Med. Chem. 2012, 7, 281.

(41) Willcock, H.; O’Reilly, R. K. Polym. Chem. 2010, 1, 149.

(42) Spruell, J. M.; Levy, B. A.; Sutherland, A.; Dichtel, W. R.; Cheng, J. Y.; Stoddart, J. F.; Nelson, A. J. Polym. Sci. Polym. Chem. 2009, 47, 346. 
The assembly of micelles into nanostructured thin films prepared by the continuous assembly of polymers (CAP) technique is presented. Macrocross-linkers based on diblock copolymers of polystyrene- $b$-poly $(N-(2-$ hydroxypropyl)methacrylamide), where the hydroxyl functionalities were partially converted to polymerizable acrylate moieties, are able to form micelles in aqueous solution. These micelles can be polymerized from initiatorfunctionalized surfaces, generating in situ cross-linked micellar films with unique pitted morphologies and hydrophobic subcompartments.

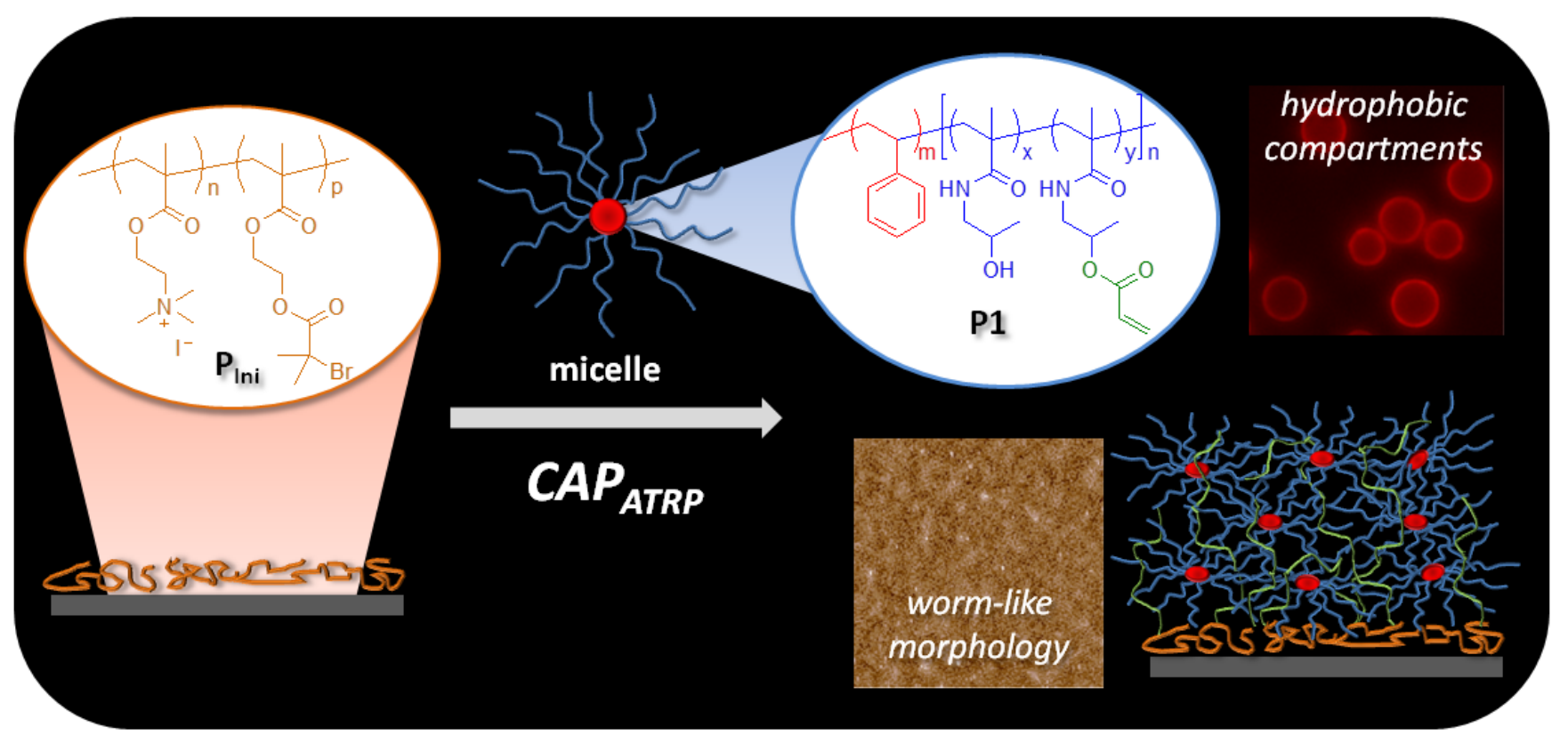




\section{University Library}

\section{- M M I N E R VA \\ A gateway to Melbourne's research publications}

Minerva Access is the Institutional Repository of The University of Melbourne

Author/s:

Wong, EHH;van Koeverden, MP;Nam, E;Guntari, SN;Wibowo, SH;Blencowe, A;Caruso,

F; Qiao, GG

Title:

Assembly of Nanostructured Films with Hydrophobic Subcompartments via Continuous Assembly of Polymers

Date:

2013-10-08

Citation:

Wong, E. H. H., van Koeverden, M. P., Nam, E., Guntari, S. N., Wibowo, S. H., Blencowe, A., Caruso, F. \& Qiao, G. G. (2013). Assembly of Nanostructured Films with Hydrophobic Subcompartments via Continuous Assembly of Polymers. MACROMOLECULES, 46 (19), pp.7789-7796. https://doi.org/10.1021/ma4017357.

Persistent Link:

http://hdl.handle.net/11343/123296 